\title{
Fluorescent chemosensor for dual-channel discrimination between phosgene and triphosgene
}

\author{
Shao-Lin Wang, Chen Li and Qin-Hua Song* \\ Department of Chemistry, University of Science and Technology of China, Hefei 230026, P. R. China \\ *E-mail: qhsong@ustc.edu.cn
}

\section{Contents:}

1. Summary of Fluorescent Chemosensors for Phosgene and Its Substitutes.........................S2-5

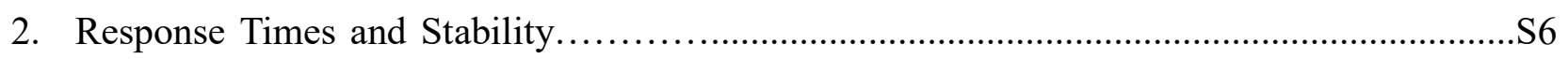

3. Evidences for the Sensing Mechanisms............................................................................ 6

4. Phos-4-embedded Fibrous Membrane for Detection of Phosgene Gas...............................S6-7

5. Details in Detection of Gaseous Phosgene.................................................................. 88

6. Copies for NMR Spectra of Phos-4, Compounds 1 and 3...........................................S9-11

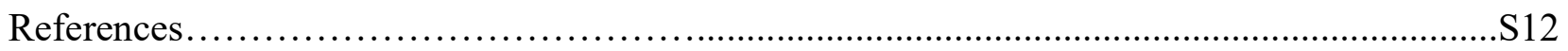


1. Summary of Fluorescent Chemosensors for Phosgene and Its Substitutes (Table S1)

\begin{tabular}{|c|c|c|c|c|c|}
\hline \multirow[t]{2}{*}{ Entry } & \multirow[t]{2}{*}{ Structures } & \multirow{2}{*}{$\begin{array}{l}\text { LOD for phosgene } \\
\text { in solutions }\end{array}$} & \multicolumn{2}{|c|}{$\begin{array}{l}\text { Response time in the certain } \\
\text { concentration }\end{array}$} & \multirow[t]{2}{*}{ References } \\
\hline & & & in solutions & gaseous phosgene* & \\
\hline 1 & & $50 \mu \mathrm{M}$ & -- & -- & Chem. Commun. 2007, 1238-1239. \\
\hline 2 & & $150 \mathrm{nM}$ & $\begin{array}{l}3 \mu \mathrm{M} \text { phosgene }{ }^{*} \\
\text { seconds }\end{array}$ & $\begin{array}{l}0 \sim 2 \times 10^{4} \mathrm{ppm} \\
20 \sim 30 \mathrm{~s}\end{array}$ & $\begin{array}{c}\text { Chem. Commun. 2012, 48, } \\
\text { 1895-1897. }\end{array}$ \\
\hline 3 & & $1 \mathrm{nM}$ & -- & -- & Anal. Chem. 2012, 84, 4594-4597. \\
\hline 4 & & $60 \mathrm{nM}$ & $\begin{array}{l}20 \mu \mathrm{M} \text { triphosgene } \\
2 \mathrm{~min}\end{array}$ & $\begin{array}{l}0 \sim 20 \mathrm{ppm} \\
\text { seconds }\end{array}$ & $\begin{array}{l}\text { Angew. Chem. Int. Ed. 2016, 55, } \\
\text { 4729-4733. }\end{array}$ \\
\hline 5 & & $9 \mathrm{nM}$ & $\begin{array}{c}150 \mu \mathrm{M} \text { phosgene } \\
20 \mathrm{~s}\end{array}$ & $\begin{array}{c}0 \sim 40 \mathrm{ppm} \\
5 \mathrm{~min}\end{array}$ & ACS Sens. 2017, 2, 178-182. \\
\hline
\end{tabular}




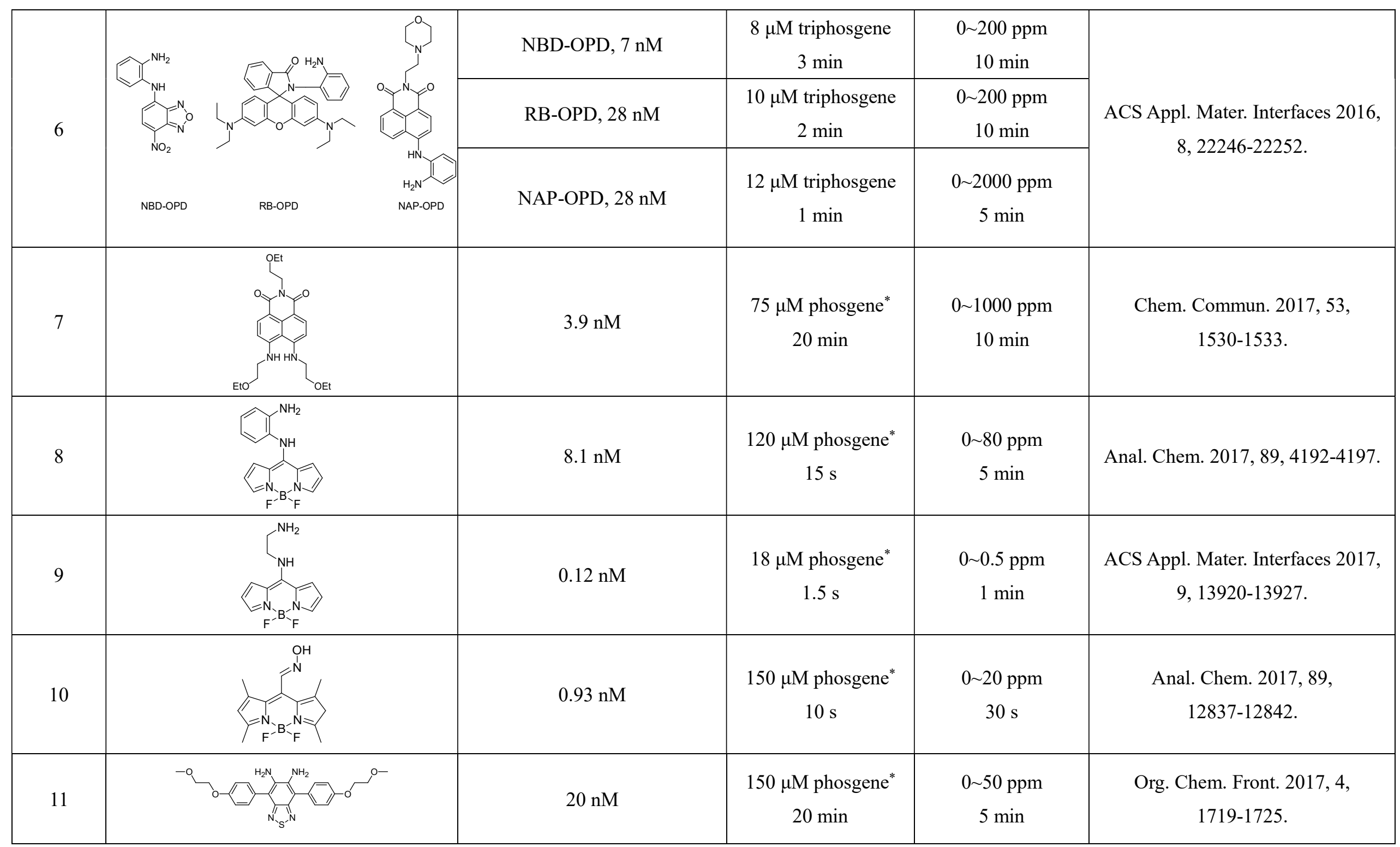




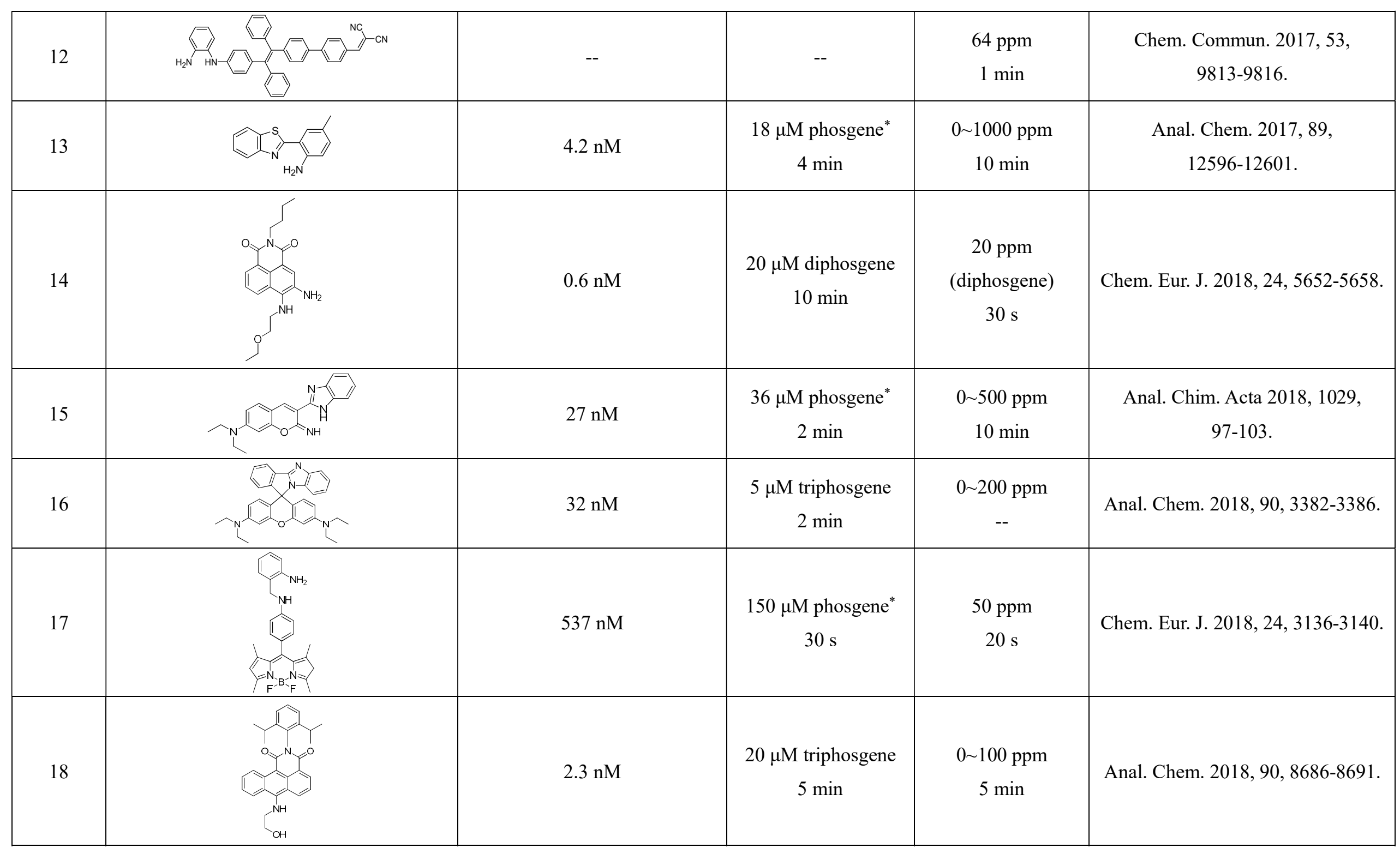




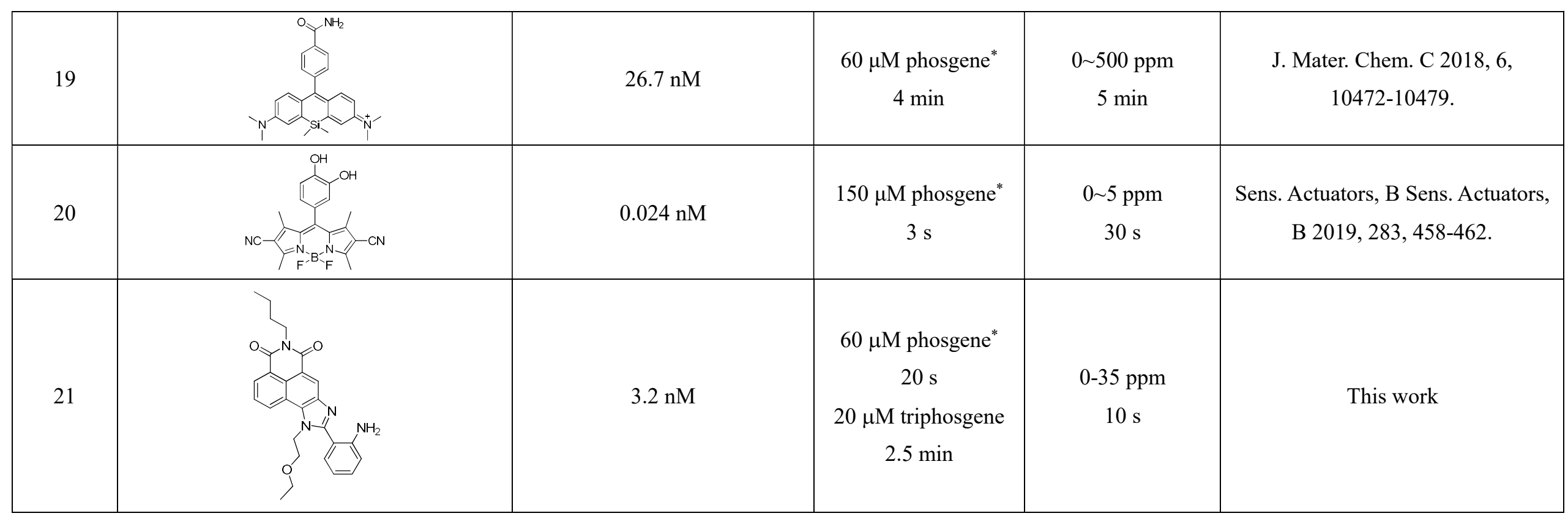

"--" Not mentioned.

* Assuming that in the presence of TEA, one mole of triphosgene can generate three mole of phosgene, unless otherwise stated. 


\section{Response Times and Stability}
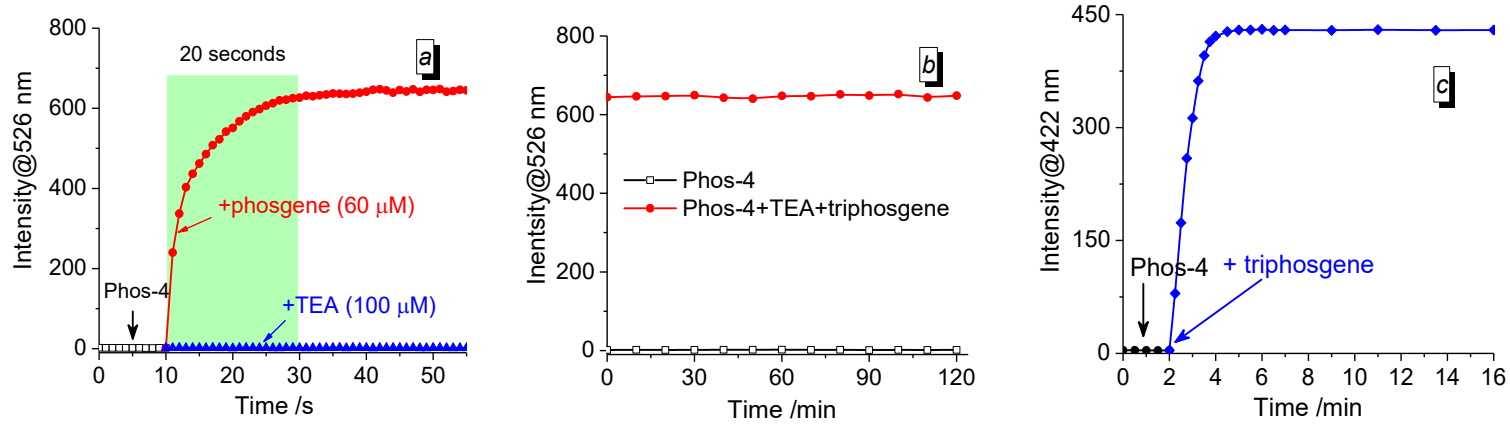

Figure S1. (a) (b) Time-dependent fluorescence intensity at $526 \mathrm{~nm}$ of Phos-4 $(10 \mu \mathrm{M})$ solution before and after addition of TEA $(100 \mu \mathrm{M})$ and phosgene [triphosgene $(20 \mu \mathrm{M}) /$ TEA $(100 \mu \mathrm{M})]$, (c) fluorescence intensity at 422 $\mathrm{nm}$ of $10 \mu \mathrm{M}$ Phos-4 upon addition of $20 \mu \mathrm{M}$ triphosgene, in 1,4-dioxane, $\lambda_{\mathrm{ex}}=390 \mathrm{~nm}$.

\section{Evidences for the Sensing Mechanism}
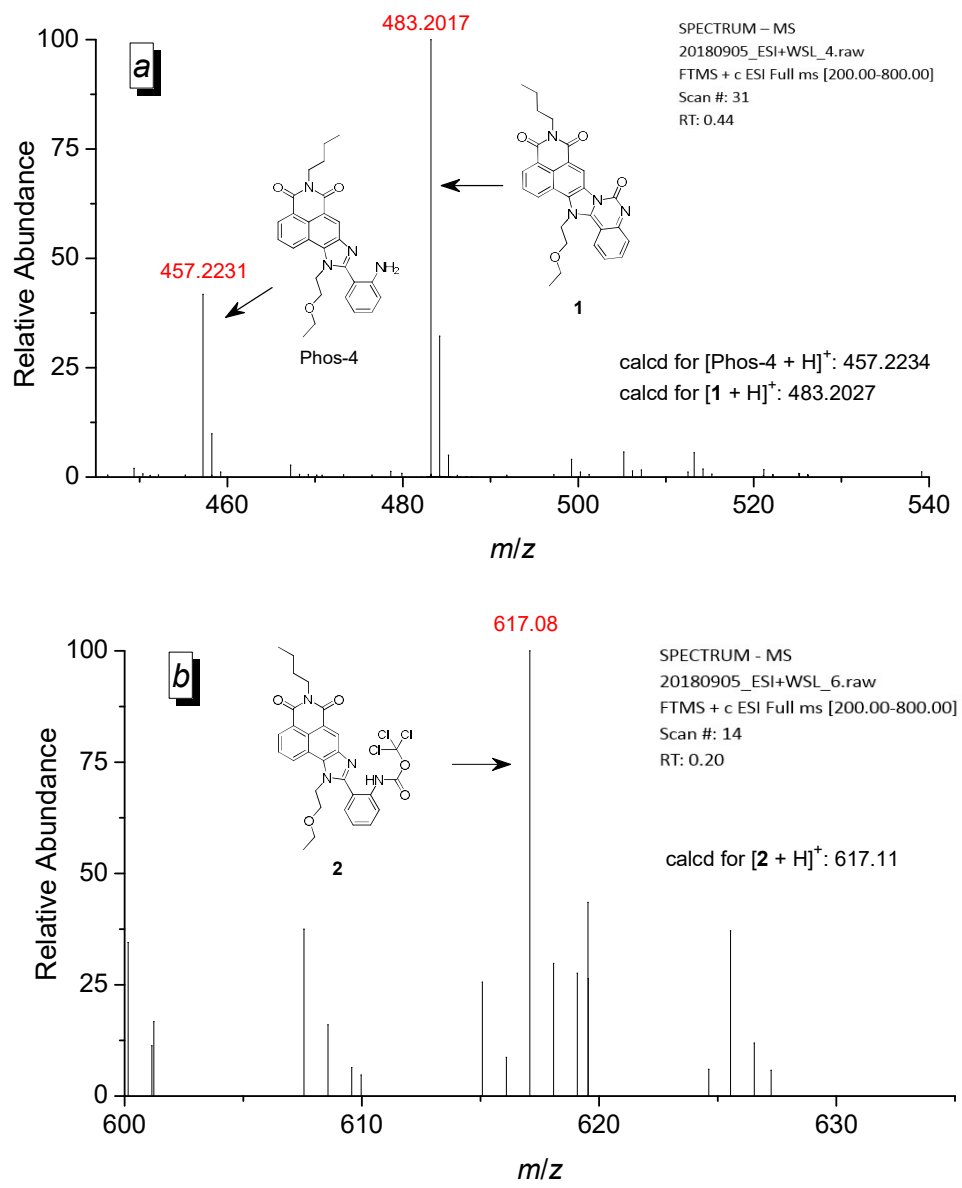

Figure S2. HRMS for the mixture of Phos-4 $(10 \mu \mathrm{M})$ reacting with (a) phosgene (30 $\mu \mathrm{M})$ or (b) triphosgene $(20$ $\mu \mathrm{M})$ in 1,4-dioxane. 


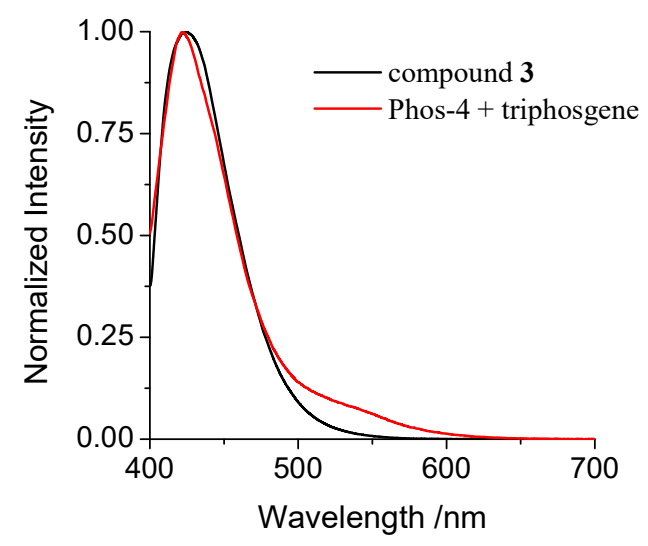

Figure S3. Normalized fluorescence spectra of $10 \mu \mathrm{M}$ compound 3 (black line), $10 \mu \mathrm{M}$ Phos-4 reacting with 20 $\mu \mathrm{M}$ triphosgene (red line) in 1,4-dioxane, $\lambda_{\mathrm{ex}}=390 \mathrm{~nm}$.

$$
\mathrm{BH}^{+} \stackrel{p K_{a}}{\rightleftharpoons} \mathrm{B}+\mathrm{H}^{+}
$$<smiles>Nc1ccccc1</smiles>

4.61<smiles>c1ccc2cc3[nH]cnc3cc2c1</smiles>

5.24<smiles>CCN(CC)CC</smiles>

10.65<smiles>Cn1cnc2ccccc21</smiles>

5.24<smiles>CC(N)=O</smiles>

$-0.51$<smiles>CC(=O)n1ccnc1</smiles>

3.60<smiles>Nc1ccc([N+](=O)[O-])cc1</smiles>

1.00<smiles>O=[N+]([O-])c1c[nH]cn1</smiles>

$-0.16$

Chart S1. The $p K_{a}$ values of some organic bases. ${ }^{\mathrm{S} 1, \mathrm{~S} 2}$ 
4. Phos-4-embedded Fibrous Membrane for Detection of Phosgene Gas
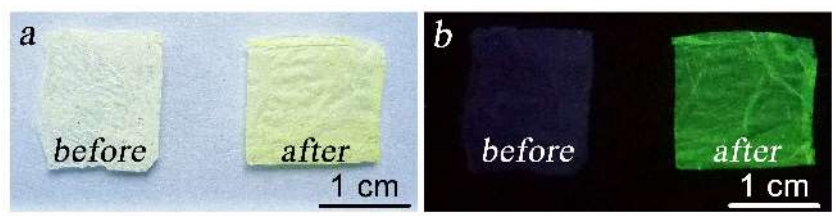

Figure S4. Photograph of Phos-4-embedded fibrous membrane before and after exposure to phosgene (10 ppm) under room light (a) and $365 \mathrm{~nm}$ light (b).

\section{Details in Detection of Gaseous Phosgene}

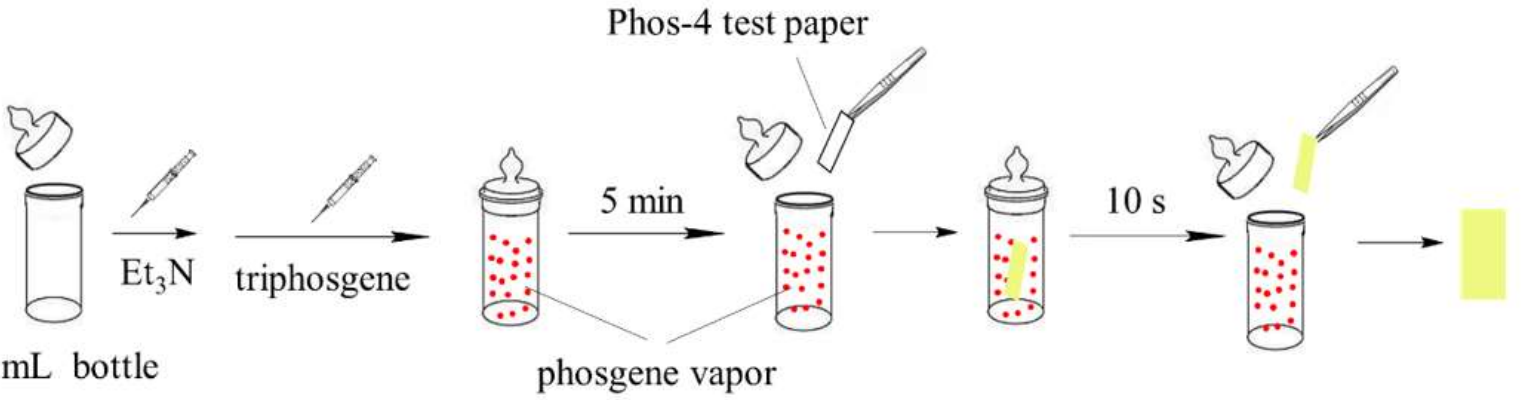

Figure S5. Procedure for evaluating response of Phos-4 test paper to gaseous phosgene.

Table S2. Calculation for the vapor concentration of gaseous phosgene

\begin{tabular}{|c|c|c|c|c|}
\hline \multirow{2}{*}{ Entry } & \multicolumn{3}{|c|}{ Concentration } & \multicolumn{2}{c|}{$\begin{array}{c}\text { Vapor concentration of } \\
\text { phosgene in } 75 \text { mL bottle }\end{array}$} \\
\cline { 2 - 5 } & $\begin{array}{c}\mid c \\
20 \mu \mathrm{L} \text { stock } \\
\text { solution of TEA } \\
/ \mathrm{mM}\end{array}$ & $\begin{array}{c}20 \mu \mathrm{L} \text { stock } \\
\text { solution of } \\
\text { triphosgene g/L }\end{array}$ & $\mathrm{mg} / \mathrm{m}^{3}$ & $\mathrm{ppm}$ \\
\hline 1 & 0 & 0 & 0 & 0 \\
\hline 2 & 0.005 & 0.015 & 4 & 1 \\
\hline 3 & 0.025 & 0.075 & 20 & 5 \\
\hline 4 & 0.05 & 0.15 & 40 & 10 \\
\hline 5 & 0.075 & 0.225 & 60 & 15 \\
\hline 6 & 0.1 & 0.3 & 80 & 20 \\
\hline 7 & 0.125 & 0.375 & 100 & 25 \\
\hline 8 & 0.15 & 0.45 & 120 & 30 \\
\hline 9 & 0.175 & 0.525 & 140 & 35 \\
\hline 10 & 0.25 & 0.75 & 200 & 50 \\
\hline
\end{tabular}


6. Copies for NMR Spectra of Phos-4, Compounds $\mathbf{1}$ and $\mathbf{3}$

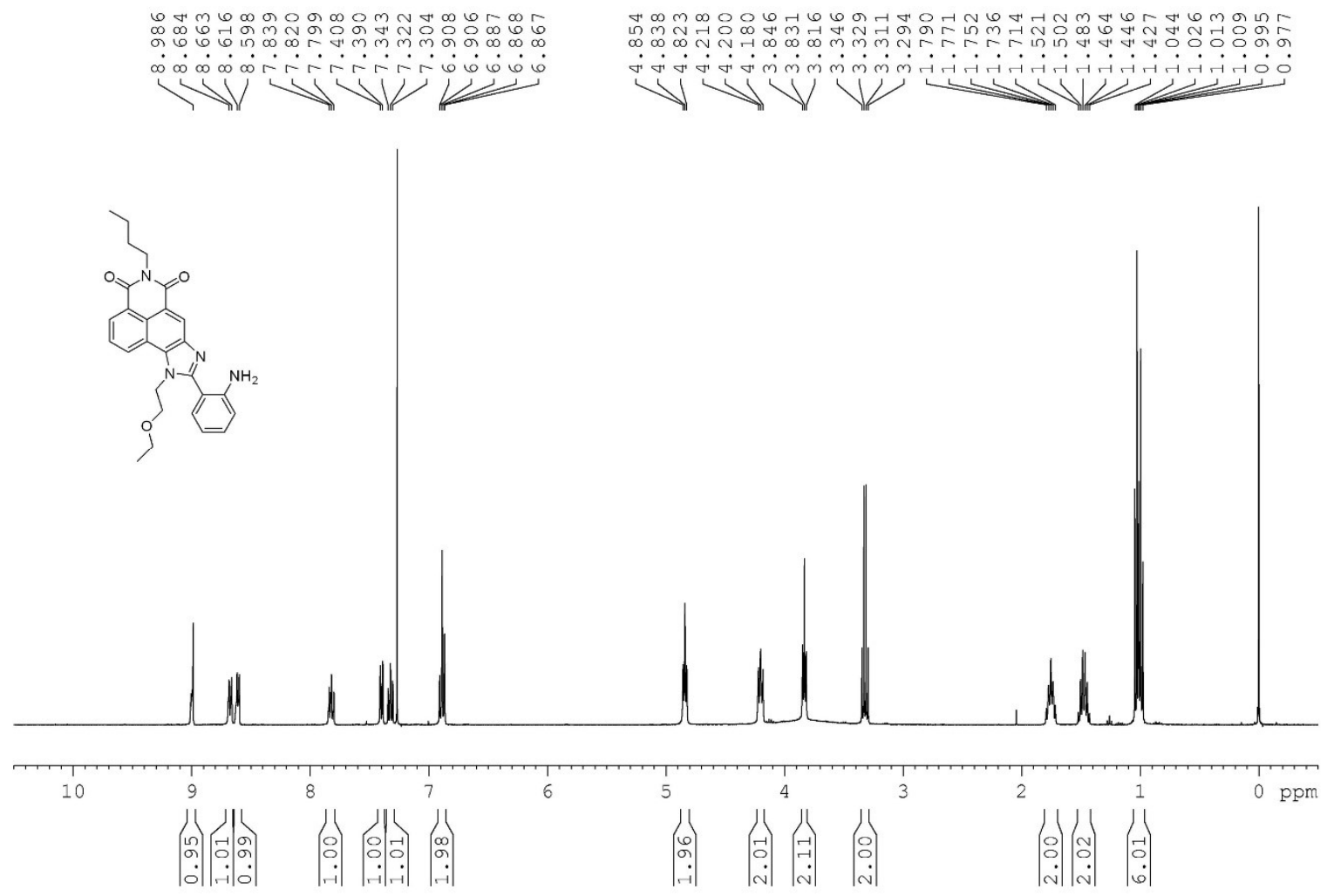

${ }^{1} \mathrm{H}$ NMR of Phos-4 in $\mathrm{CDCl}_{3}$

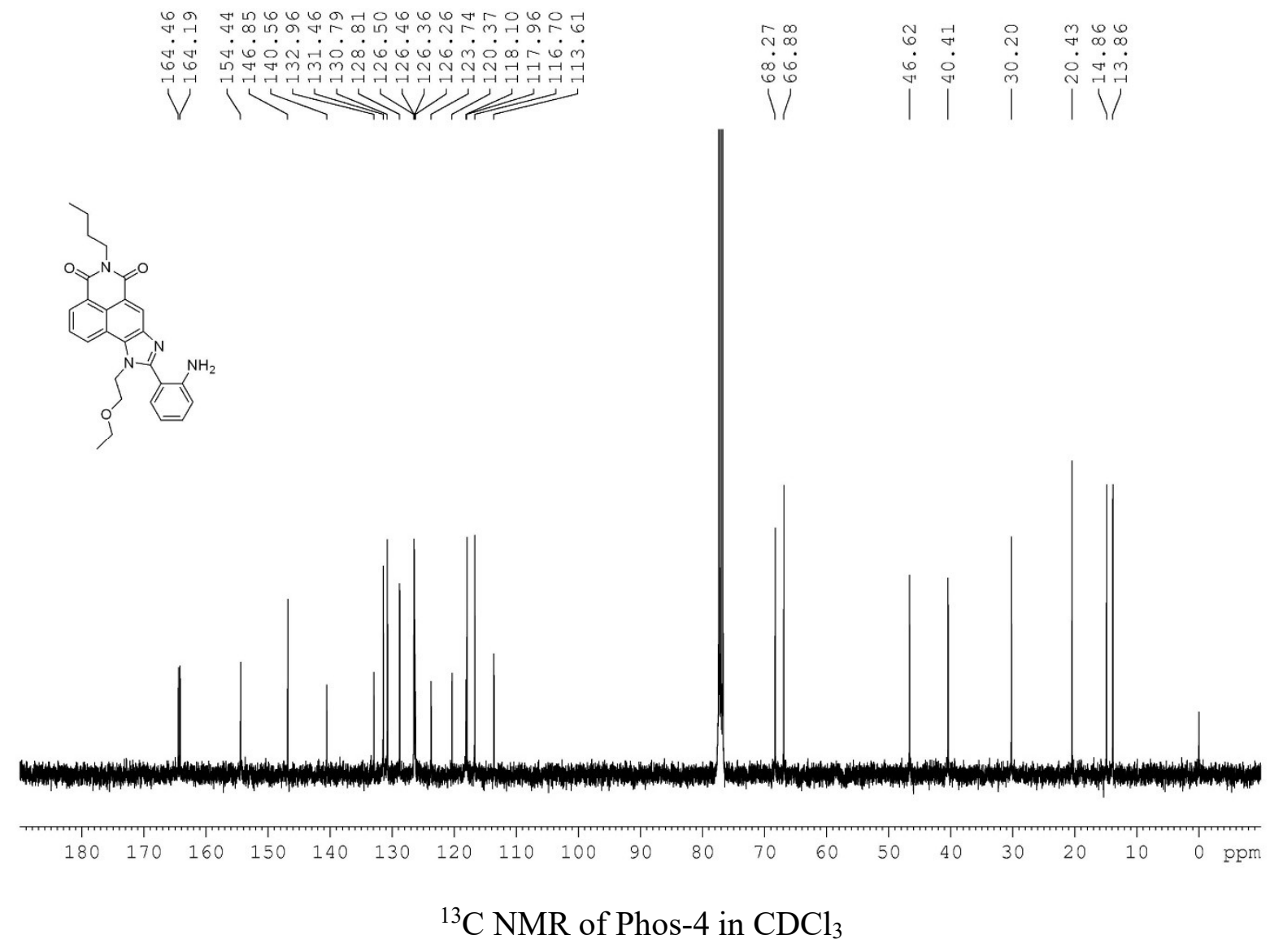




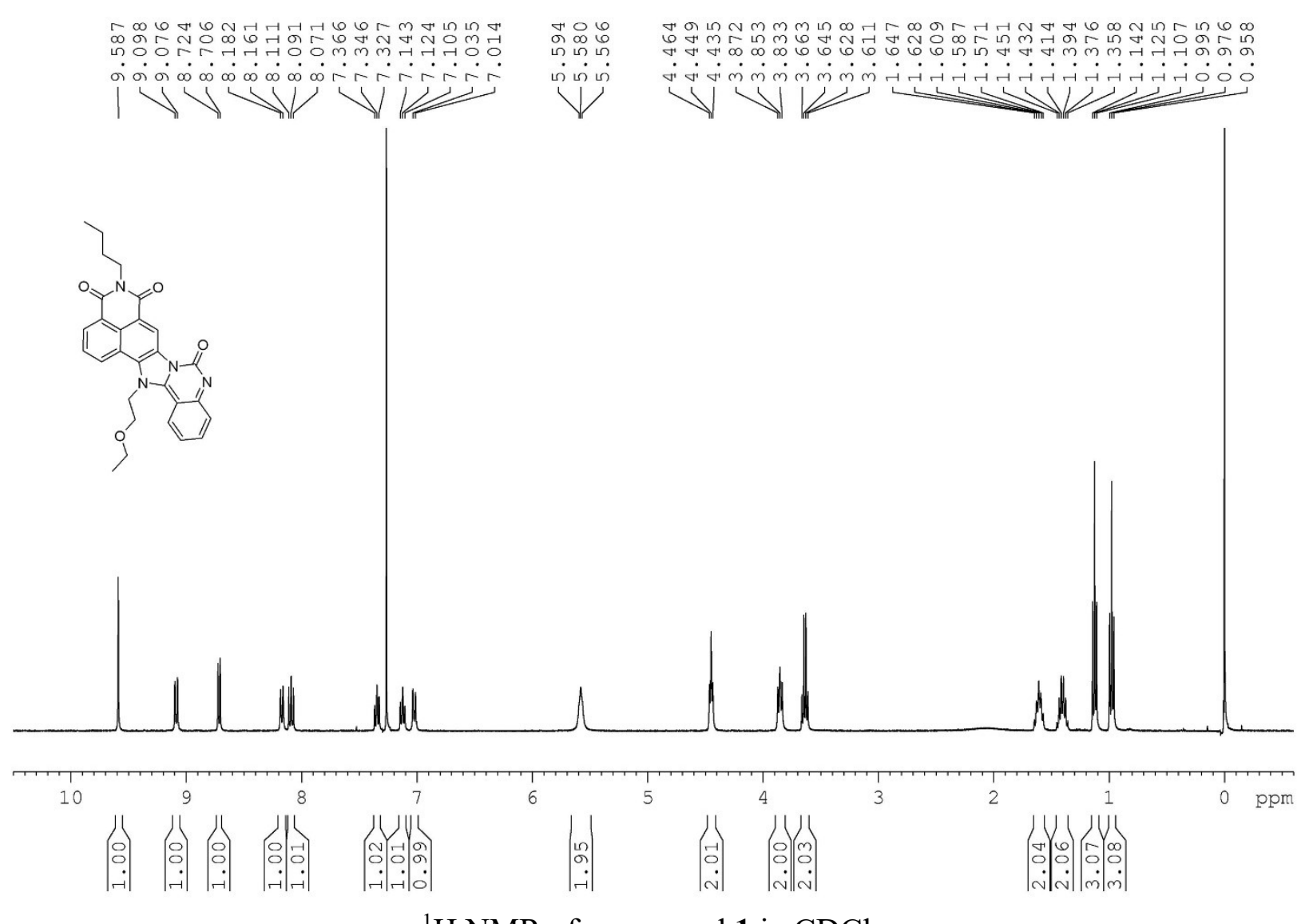

${ }^{1} \mathrm{H}$ NMR of compound $\mathbf{1}$ in $\mathrm{CDCl}_{3}$

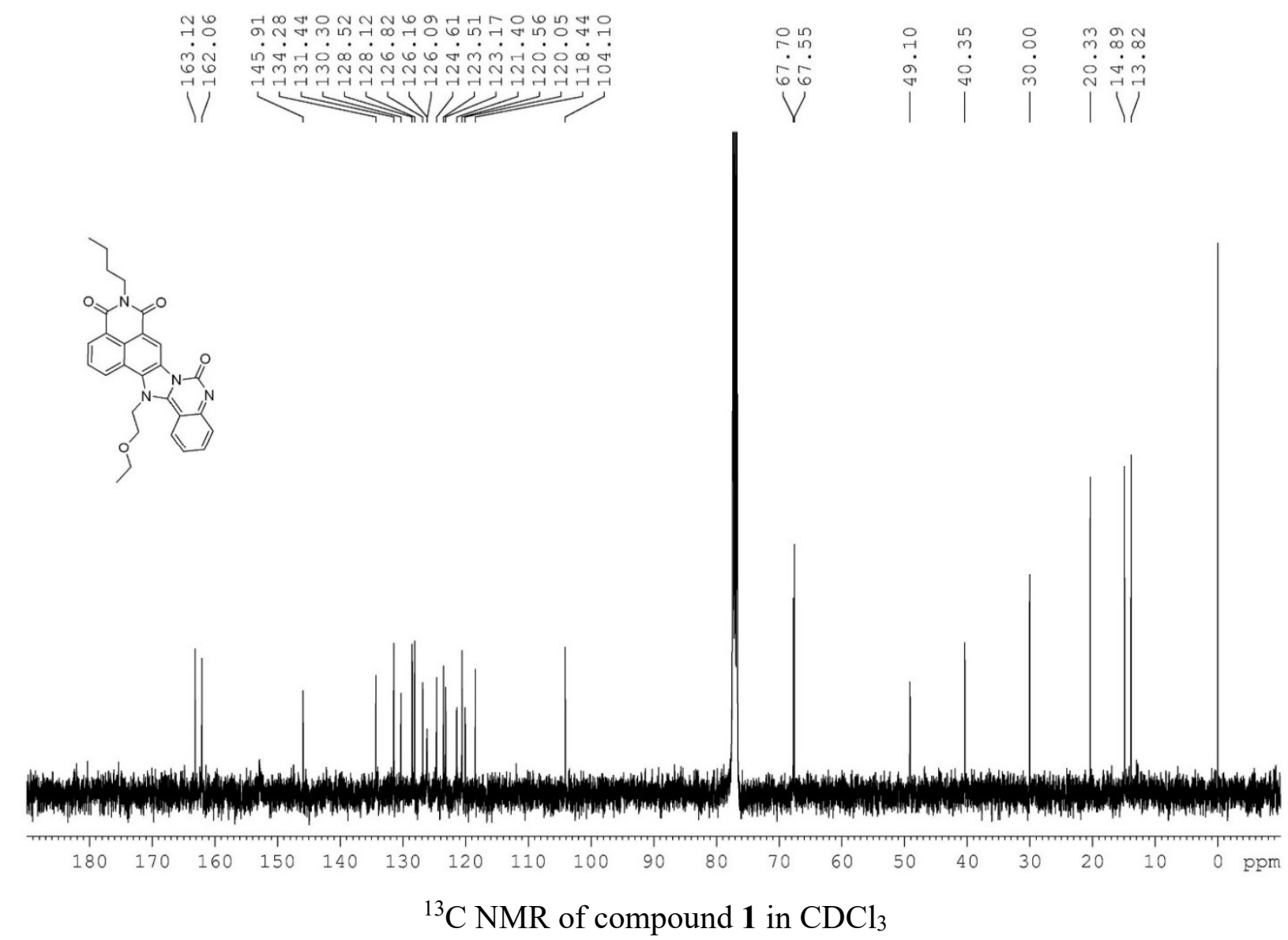




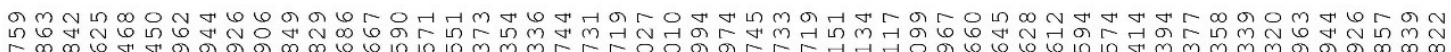
作

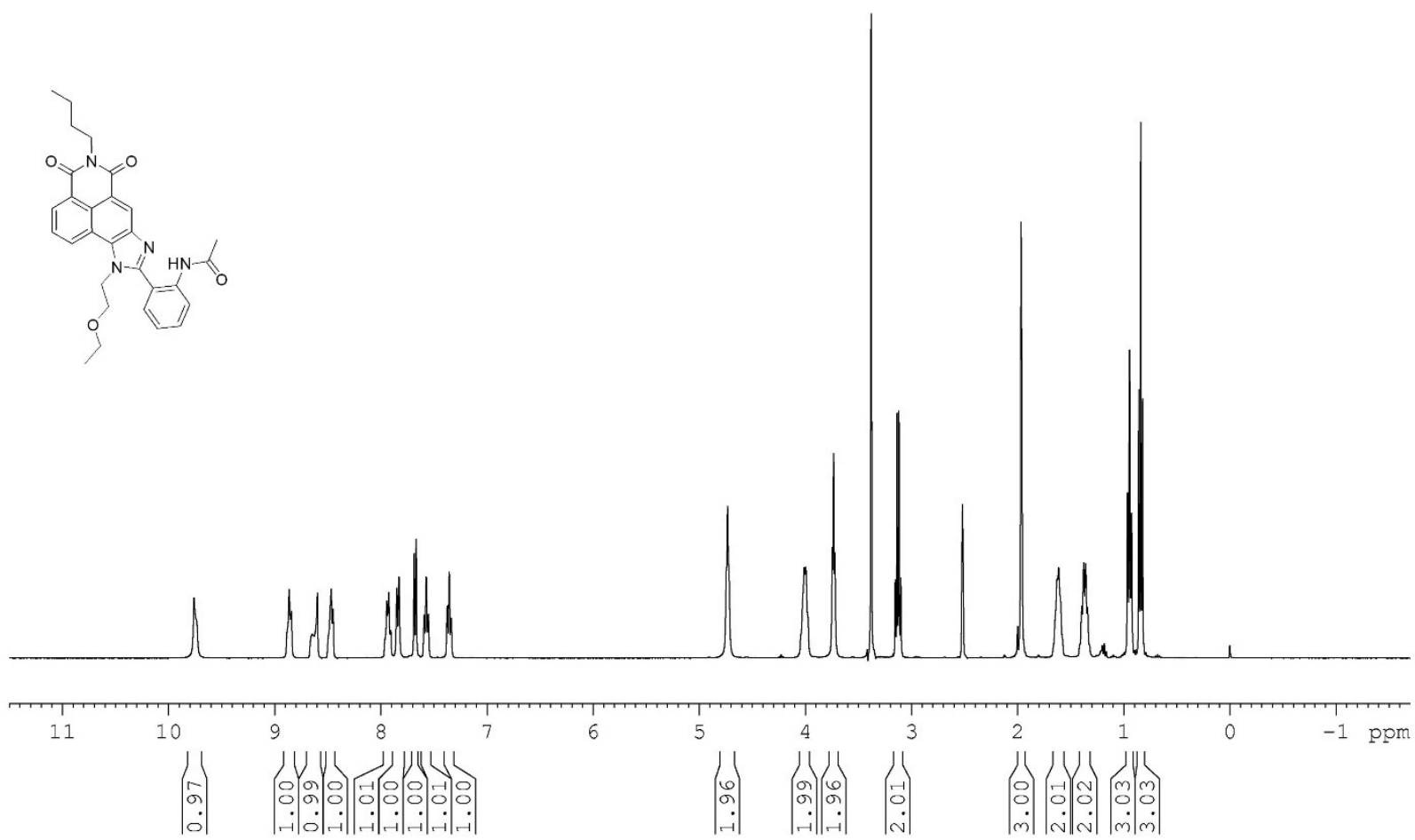

${ }^{1} \mathrm{H}$ NMR of compound 3 in DMSO- $d_{6}$
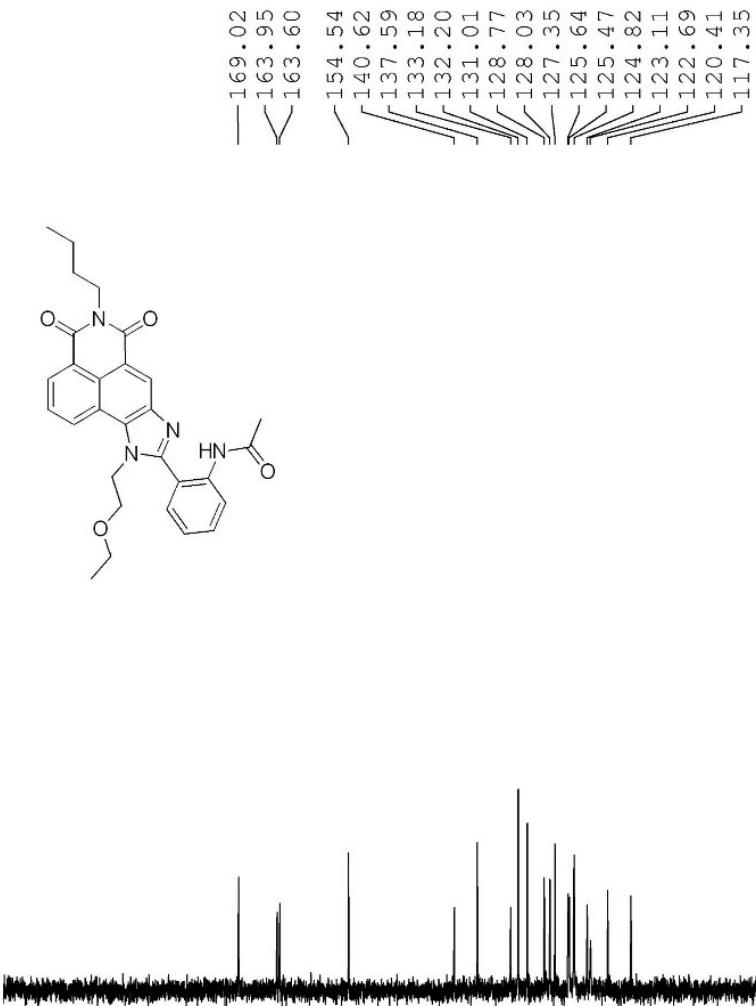

$\begin{array}{llllll}190 & 180 & 170 & 160 & 150 & 1\end{array}$

${ }^{13} \mathrm{C}$ NMR of compound 3 in DMSO- $d_{6}$ 


\section{References}

S1 Zhang, S. A Reliable and Efficient First Principles-Based Method for Predicting $p K a$ Values. 4. Organic Bases. J. Comput. Chem. 2012, 33, 2469-2482.

S2 Handbook of Chemistry and Physics, Editor in Chief, Charles D. hodgman, M.S.; Chemical Rubber Publishing Company, Cleveland, OH, 1951, p. 1636-7 